\title{
Activated Proliferation of B-Cell Lymphomas/Leukemias with the SHP1 Gene Silencing by Aberrant CpG Methylation
}

\author{
Maho Koyama, Takashi Oka, Mamoru Ouchida, Yoko Nakatani, Ritsuo Nishiuchi, \\ Tadashi Yoshino, Kazuhiko Hayashi, Tadaatsu Akagi, and Yoshiki Seino
}

Department of Pediatrics, (MK, RN, YS), Department of Pathology (TO, YN, TY, KH, TA), and Department of Molecular Genetics (MO), Graduate School of Medicine and Dentistry, Okayama University, Okayama, Japan

\begin{abstract}
SUMMARY: Previously we showed reduced protein and mRNA expression of the SHP1 gene in lymphoma/leukemia cell lines and patient specimens by Northern blot, RT-PCR, Western blot, and immunohistochemical analyses. In this study, aberrant methylation in the SHP1 gene promoter was detected in many B-cell leukemia/lymphoma cell lines as well as in patient specimens, including diffuse large B-cell lymphoma (methylation frequency 93\%), MALT lymphoma (82\%), mantle cell lymphoma (75\%), plasmacytoma (100\%) and follicular lymphoma (96\%) by methylation-specific PCR, bisulfite sequencing, and restriction enzyme-mediated PCR analyses. The methylation frequency was significantly higher in high-grade MALT lymphoma cases $(100 \%)$ than in low-grade MALT lymphoma cases $(70 \%)$, which correlated well with the frequency of no expression of SHP1 protein in high-grade (80\%) and low-grade MALT lymphoma (54\%). It suggests that the SHP1 gene silencing with aberrant CpG methylation relates to the lymphoma progression. SHP1 protein expression was recovered in B-cell lines after the treatment of the demethylating reagent: 5-aza-2'-deoxycytidine. Transfection of the intact SHP1 gene to the hematopoietic cultured cells, which show no expression of the SHP1 gene, induced growth inhibition, indicating that gene silencing of the SHP1 gene by aberrant methylation plays an important role to get the growth advantage of the malignant lymphoma/leukemia cells. The extraordinarily high frequency (75 to $100 \%$ ) of $\mathrm{CpG}$ methylation of the SHP1 gene in B-cell lymphoma/leukemia patient specimens indicates that the SHP1 gene silencing is one of the critical events to the onset of malignant lymphomas/leukemias as well as important implications for the diagnostic or prognostic markers and the target of gene therapy. These data support the possibility that the SHP1 gene is one of the tumor suppressor genes. (Lab Invest 2003, 83:1849-1858).
\end{abstract}

$T$ he growth and many functional responses of hematopoietic cells are regulated through the phosphorylation of tyrosine residues in proteins. The gene encoding the cytoplasmic protein tyrosine phosphatase SHP1 (also termed PTP1C, PTPN6, HCP, and SHPTP1) is commonly expressed in hematopoietic cells. SHP1 was found to be an important negative regulator of antigen receptor-mediated signaling and selection in B-lymphocytes (Cyster and Goodnow, 1995; Pani et al, 1995). SHP1 also has a significant role in the regulation of $\mathrm{T}$-cell responses to antigen receptor-mediated stimulation, with its effects on signaling pathways evoked by T-cell receptor (TCR) engagement, which is predominantly inhibitory (Carter et al, 1999; Lorenz et al, 1996; Pani et al, 1996).

\section{DOI: 10.1097/01.LAB.0000106503.65258.2B}

Received June 10, 2003.

Supported by the Ministry of Education, Culture, Sports, Science, and Technology of Japan to T.O. (No. 12670161). Sequence data of the SHP1 genomic DNA have been deposited in DDBJ/EMBL/Genbank with Accession No. AB079851.

Address reprint requests to: Dr. Takashi Oka, Department of Pathology, Graduate School of Medicine and Dentistry, Okayama University, 2-5-1 Shikata-cho, Okayama 700-8558, Japan. E-mail: oka@md. okayama-u.ac.jp
Cancer can be regarded as an epigenetic disease as well as a genetic disease. The genomes of transformed cells undergo simultaneous global genomic hypomethylation and dense hypermethylation of $\mathrm{CpG}$ islands associated with gene regulatory regions (Brown and Strathdee, 2002). The reciprocal relationship between the density of methylated cytosine residues and intensity of a gene expression has been widely documented (Razin and Cedar, 1991). Dramatic changes in methylation are thought to lead to chromosomal instability, loss of imprinting, activation of endogenous viruses, illegitimate expression, aneuploidy, mutation, and may also contribute to the epigenetic transcriptional repression of tumor suppressor genes in a wide variety of tumor types (Brown and Strathdee, 2002; Esteller and Herman, 2002). Hypermethylation-associated inactivation affects virtually all pathways in the cellular network, including DNA repair (hMLH1 [Fleisher et al, 1999; Herman et al, 1998], BRCA1 [Esteller et al, 2000], MGMT [Esteller et al, 1999a]), the cell cycle (p16INK4a [Herman et al, 1995; Merlo et al, 1995], p14ARF [Greger et al, 1989; Robertson and Jones, 1998], p15INK4b [Herman et al, 1996], Rb [Greger et al, 1989; Sakai et al, 1991], apoptosis [DAPK; Esteller et al, 1999b; Katzenellenbogen et al, 1999], caspase 8 [Fulda et al, 2001]) and the $\mathrm{APC} / \beta$-catenin/E-cadherin network (Esteller et al, 
2001). The frequency of promoter methylation that results in gene inactivation is reported to be about $9 \%$ for the $R B 1$ gene in retinoblastoma (Ohtani-Fujita et al, 1997), 33\% for the VHL gene in Von Hippel Lindau disease (Prowse et al, 1997), and 84\% for the MLH1 gene in microsatellite-unstable colorectal tumors (Herman et al, 1998). Thus, promoter methylation seems to represent a significant step in human carcinogenesis.

Recently, we comprehensively and systematically analyzed the mRNA and protein expression patterns of a number of malignant lymphoma and leukemia patient specimens and cell lines by cDNA expressionarrays and tissue microarrays, and we found that SHP1 mRNA and protein levels were strongly decreased, which were confirmed by RT-PCR and Western blot analyses, respectively (Oka et al, 2001). In the present study, we analyzed the SHP1 gene expression and DNA methylation patterns of various B-cell lymphomas/leukemias and defined the relationship between the SHP1 gene silencing and DNA methylation.

\section{Results}

As we had previously detected a marked decrease in SHP1 mRNA and protein in lymphomas/leukemias including NK cell lymphoma by cDNA expressionarray and tissue microarray experiments (Oka et al, 2001), we investigated SHP1 protein expression in various hematopoietic cell lines by Western blot analysis (Fig. 1A). SHP1 protein was detected in normal fresh peripheral blood mononuclear cells (PBMCs). However, no expression of the SHP1 gene was observed in the CML (K562), B-ALL (SCOTT and KW), Burkitt lymphoma (Ramos and Daudi), Hodgkin's disease (HDLM2 and L428), and multiple myeloma (U266) cell lines as well as in the natural killer/T-lymphoma cell line (NK-YS). Analysis of the SHP1 gene transcription by RT-PCR showed similar tendency to that of SHP1 protein level (Fig. 1B). To investigate the mechanism responsible for the reduced SHP1 gene expression in lymphoma/leukemia cell lines, we analyzed the promoter region of the SHP1 exon 1b, known to be expressed in a hematopoietic cell-specific manner, by methylation-specific PCR (MSP) and unmethylationspecific PCR (unMSP) (Fig. 1C). MSP products of the $\mathrm{CpG}$ island were shown in the NK-YS, K562, Daudi, HDLM2, L428, U266 and RPMI8226 cell lines, and weak products observed in SCOTT, KW, SP50B, and Ramos cell lines. In contrast, no MSP signals were detected in normal PBMCs. Unmethylation-specific PCR revealed that normal PBMCs and some cell lines, which express SHP1 mRNA and protein, showed strong unmethylation-specific signals. These results suggest that the ratio of methylation/unmethylation signals in the promoter correlate well with the reduced SHP1 gene expression (Fig. 1C; Table 1). These data were confirmed by restriction enzyme-mediated PCR (RE-PCR) as well (Fig. 1D). We then investigated the SHP1 gene products in diagnostic samples from malignant B-cell lymphoma patients. No SHP1 protein expression was observed in 23 of 24 cases (95.8\%) of diffuse large B-cell lymphoma (DLBCL), 22 of 36 cases

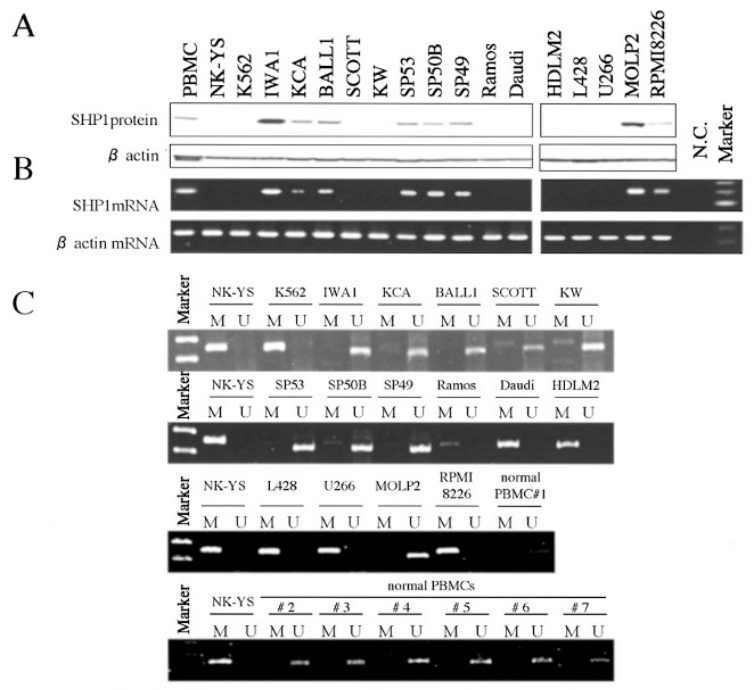

$\begin{aligned} & \text { normal PBMCs } \\ & \text { SHP1 protein }\end{aligned}$
$\beta$ actin protein

$\mathrm{D}$

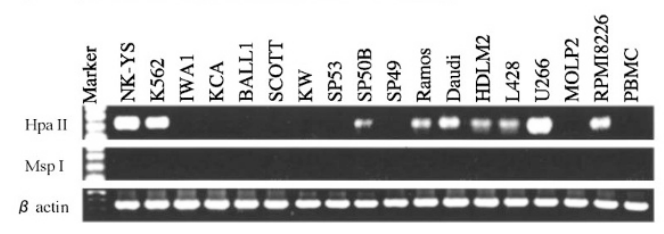

Figure 1.

Analysis of the SHP1 gene expression and methylation in various hematopoietic cell lines. (A) Western blot analysis of SHP1 protein expression. Cell lysates extracted from $7.5 \times 10^{4}$ cells cultured under standard conditions were subjected to SDS-PAGE, blotted onto membranes and probed with anti-SHP1 or anti- $\beta$ actin antibodies. (B) RT-PCR analysis of the SHP1 gene. SHP1 and $\beta$ actin cDNA were amplified by RT-PCR, then separated by $1.5 \%$ agarose gel electrophoresis. N.C. indicates the negative control, which did not contain CDNA. (C) MSP and unMSP assays of the SHP1 promoter in hematopoietic cell lines and normal peripheral blood mononuclear cells (PBMCs). $M$ and $U$ indicate methylation and unmethylation specific PCR, respectively. (D) Restriction enzymes-mediated PCR of the SHP1 promoter region in hematopoietic cell lines and normal PBMC. DNA was digested with Hpall or Mspl for PCR.

(61.1\%) of marginal zone lymphoma MALT type (MALT Iymphoma), 12 of 13 cases $(92.3 \%)$ of mantle cell lymphoma (MCL), 17 of 17 cases (100\%) of plasmacytoma, and 14 of 14 cases (100\%) of follicular lymphoma $(\mathrm{FL})$, as shown by tissue microarray and standard immunohistochemistry (Fig. 2A; Table 2). These results were in clear contrast to the presence of SHP1 protein in 10 of 10 mantle zone samples (100\%) and 10 of 10 interfollicular zone samples (100\%) from the reactive lymphoid hyperplasia (RLH) cases (Fig. 2A-a; Table 2). By MSP analysis, approximately $93.3 \%$ of DLBCL (42/45), $82.4 \%$ of MALT Iymphoma (14/17), $75 \%$ of MCL (3/4), $100 \%$ of plasmacytoma (5/5), and $95.8 \%$ of FL (23/24) patient specimens showed methylation at the SHP1 gene promoter CpG island (Fig. 2B; Table 2). The SHP1 gene CpG island methylation was significantly more frequent in high grade MALT lymphoma (DLBCL with MALT lymphoma) (100\%; 7/7) compared with low grade MALT Iymphoma (70\%; $7 / 10$ ) cases, which correlate well with the frequency of no expression of SHP1 protein in high-grade (80\%) and low-grade MALT lymphoma (54\%). The high fre- 
Table 1. The Summary of All the Experiments in Cell Lines

\begin{tabular}{|c|c|c|c|c|c|c|c|}
\hline \multirow[b]{2}{*}{ Cell line } & \multirow[b]{2}{*}{ Origin } & \multicolumn{3}{|c|}{ SHP1 gene methylation } & \multirow{2}{*}{$\begin{array}{l}\text { SHP1 gene } \\
\text { rearrangement }^{a}\end{array}$} & \multirow{2}{*}{$\begin{array}{l}\text { SHP1 protein } \\
\text { expression }^{b}\end{array}$} & \multirow{2}{*}{$\begin{array}{c}\text { SHP1 } \\
\text { mRNA } \\
\text { expression }^{c}\end{array}$} \\
\hline & & RE-PCR & MSP & unMSP & & & \\
\hline NK-YS & NK/T-Ly & +++ & +++ & - & - & - & - \\
\hline K562 & CML & ++ & +++ & - & - & - & - \\
\hline IWA1 & $\mathrm{T}(\mathrm{HTLV}-1)$ & - & - & + & - & +++ & ++ \\
\hline $\mathrm{KCA}$ & B-ALL & - & - & + & - & + & + \\
\hline BALL1 & B-ALL & - & - & + & - & + & + \\
\hline SCOTT & B-ALL & - & + & + & - & - & - \\
\hline KW & B-ALL & - & + & ++ & - & - & - \\
\hline SP53 & MCL & - & - & ++ & - & + & ++ \\
\hline SP50B & MCL & + & \pm & ++ & - & + & ++ \\
\hline SP49 & MCL & - & - & ++ & - & + & ++ \\
\hline Ramos & Burkitt Ly & + & + & - & - & - & - \\
\hline Daudi & Burkitt Ly & ++ & ++ & - & - & - & - \\
\hline HDLM2 & HD & + & ++ & - & - & - & - \\
\hline L428 & HD & + & +++ & - & - & - & - \\
\hline U266 & MM & +++ & +++ & - & - & - & - \\
\hline MOLP2 & MM & - & - & ++ & - & ++ & ++ \\
\hline RPMI8226 & MM & ++ & +++ & + & - & + & + \\
\hline PBMCs & Healthy volunteer & - & - & + & - & + & + \\
\hline
\end{tabular}

PBMCs, peripheral blood mononuclear cells; Ly, lymphoma; CML, chronic myelogenous leukemia; T(HTLV-1), HTLV-1-immortalized normal human T cell; ALL, acute lymphoblastic leukemia; MCL, mantle cell lymphoma; HD, Hodgkin's disease; MM, multiple myeloma; RE-PCR, restriction enzymes-mediated polymerase chain reaction; MSP, methylation-specific polymerase chain reaction; unMSP, unmethylation-specific polymerase chain reaction.

The strength of the SHP1 bands was indicated according to the intensity from,,,++++++ to \pm . - indicates completely negative for SHP1 band.

a Detected by Southern blot analysis.

${ }^{b}$ Detected by Western blot analysis.

${ }^{c}$ Detected by RT-PCR.

quency of the SHP1 gene methylation in patient specimens was confirmed by RE-PCR analysis (data not shown). Some patient specimens, such as L1844, L1675, and L1568, showed positive signals for both MSP and unMSP (Fig. 2B). To address the question of whether the lymphoma cells themselves have totally methylated SHP1 DNA and are contaminated with the inflammatory cells or infiltrating normal PBMCs supplying the unmethylated DNA for MSP analysis, we performed bisulfite DNA sequencing to determine the methylation of $22 \mathrm{CpG}$ sites within the 519 bp region of the SHP1 promoter that included the region examined by MSP, unMSP, and RE-PCR analyses (Fig. 3). K562 and HDLM2 cell lines, which showed strong methylation signals by both MSP and RE-PCR analyses without signals by unMSP(Fig. 1, C and D), were hypermethylated in all clones analyzed by bisulfite DNA sequencing (Fig. 3). It indicates that tumor cells, which totally methylated in the $\mathrm{CpG}$ island of the SHP1 gene, do not express SHP1 protein (Fig. 1A; Fig. 3). In contrast, almost no methylation was detected by bisulfite DNA sequencing (Fig. 3) in all clones of IWA1 and normal PMBC, which showed no methylation signals by MSP and RE-PCR analyses and strong SHP1 protein expression by Western blot analysis (Fig. 1). For the lymphoma patient specimens such as L1844, L1675, and L1568, some clones showed hypermethylation, whereas others showed hypomethylation. These results suggest that the lymphoma patient specimens contained both blastic lymphoma cells and also contaminated normal cells that exhibited hypermethylation and hypomethylation, respectively.

To investigate whether the reduced SHP1 gene expression could be rescued by demethylation treatment, cell lines were treated with the demethylating reagent 5-aza-2'-deoxycytidine (5AzaCdR) (Fig. 4). Some cell lines, such as MT1, KW, and L428, expressed SHP1 protein in response to this treatment, whereas weak induction was detected in the cell lines HDLM2 and RPMI8226. However, no induction was detected in the U266. To ensure that intact SHP1 alleles were retained in the U266 cell line, we performed Southern blot analysis. Neither definite rearrangements nor deletions of the SHP1 gene were detected by this method (data not shown; Table 1). To clarify the effect of over-expression of the SHP1 gene on cell growth, K562 cells transfected with SHP1 expression vector or empty vector were assayed after selection with G418 for 7 days (Fig. 5). The result showed that cell growth of the SHP1 gene-transfected cells was significantly suppressed as compared with that of control cells $(p=0.0003)$.

\section{Discussion}

Reduced expression of SHP1 protein and mRNA was detected in various B-cell leukemia and lymphoma cell lines, and clearly correlated with the level of SHP1 gene promoter methylation, as detected by MSP, RE-PCR, and bisulfite DNA sequencing. Our results suggest that methylation of the SHP1 gene CpG island 
A
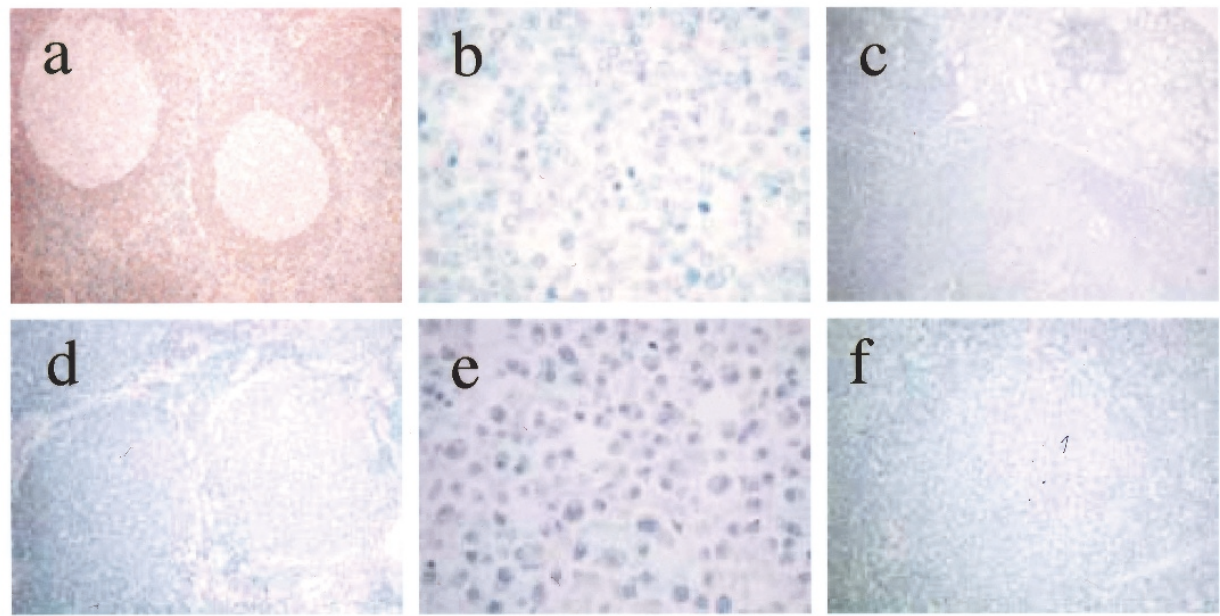

\section{B}
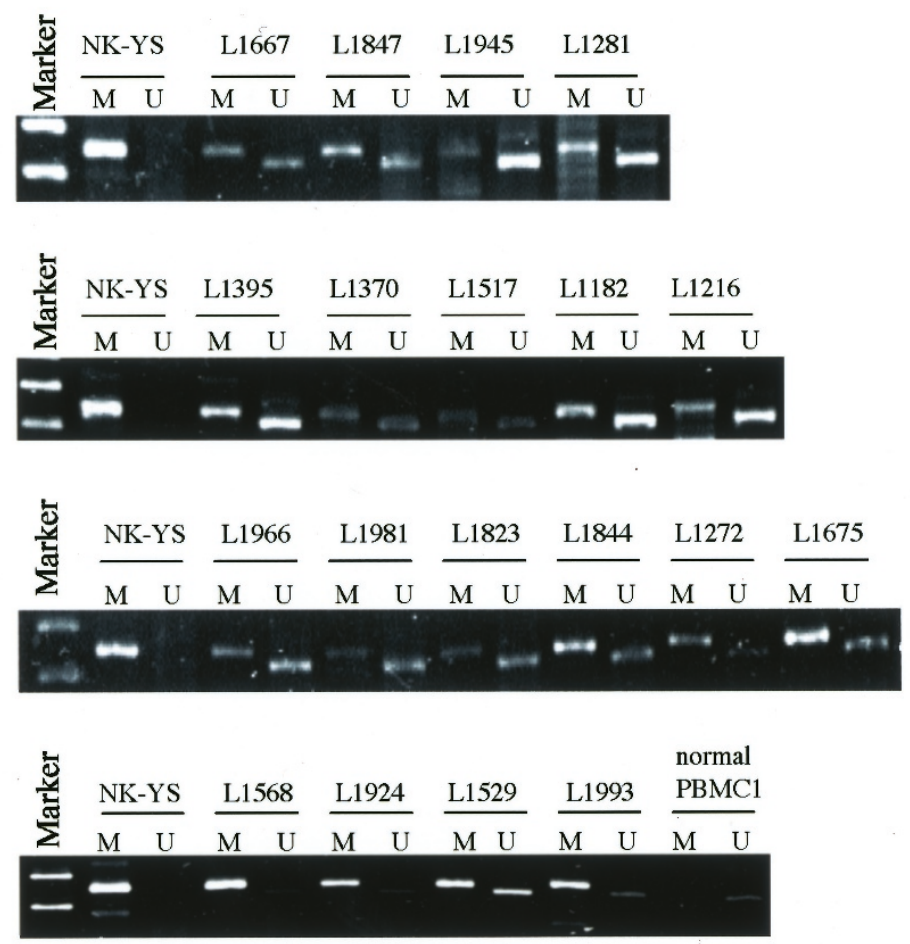

Figure 2.

The SHP1 gene expression and methylation analyses of patient specimens. (A) Immunohistochemistry of SHP1 protein in a case of reactive lymphoid hyperplasia (a); diffuse large B cell lymphoma (DLBCL) (b); marginal zone lymphoma MALT type (MALT Iymphoma) (c); mantle cell lymphoma (MCL) (d); plasmacytoma (e); and follicular lymphoma (FL) (f). (B) Methylation-specific PCR (MSP) and unmethylation-specific PCR (unMSP) assays of the SHP1 promoter in patient specimens. $\mathrm{M}$ and $\mathrm{U}$ indicate methylation and unmethylation, respectively. DLBCL specimens, L1966, 1981, 1823, and 1844; MALT Iymphoma specimens, L1667, 1847, 1272, 1675, 1568, and 1924; FL specimens, L1945, 1281, 1395, 1370, 1517, 1182, 1216, 1529, and 1993.

is the important mechanism for the reduced SHP1 gene expression.

With regard to the patient specimens, 75 to $100 \%$ of DLBCL, MALT lymphoma, MCL, plasmacytoma, and FL cases showed the SHP1 gene CpG island methylation by MSP, whereas reduced SHP1 protein expression was detected by immunohistochemistry at a slightly higher frequency (90 to $100 \%)$. This discrepancy may mean that protein level detection using an anti-SHP1 antibody underestimates the actual amount, and/or that there may be some other mechanism for the reduction of the SHP1 gene products in addition to DNA methylation. Indeed, treatment with the demethylation reagent $5 \mathrm{AzaCdR}$ failed to induce SHP1 protein expression in the U266 cell line despite the successful induction of SHP1 protein in the MT1, KW, HDLM2, L428, and RPMI8226 cell lines. Southern blot analysis data indicated that at least one SHP1 allele was retained in the U266 cell line. Histone modification, such as by acetylation, methylation, or phosphorylation, may represent other mechanisms of the reduced SHP1 gene expression (Chung, 2002; Jenuwein and Allis, 2001), and remains for further investigation in this case. 
Table 2. Expression of SHP1 Protein and CpG Island Methylation of the SHP1 Gene in Malignant Lymphomas

\begin{tabular}{|c|c|c|c|c|c|}
\hline \multirow[b]{2}{*}{ Diagnosis } & \multirow[b]{2}{*}{ Subtype } & \multicolumn{3}{|c|}{ SHP1 protein ${ }^{a}(\%)$} & \multirow{2}{*}{$\begin{array}{l}\text { SHP1 gene } \\
\text { methylation } \\
(\%)\end{array}$} \\
\hline & & ++ & + & - & \\
\hline \multirow{3}{*}{ DLBCL } & Nodal & $1 / 12^{c}(8.3)$ & 0/12 (0) & $11 / 12(91.7)$ & $23 / 26(88.5)$ \\
\hline & Extranodal & $0 / 12(0)$ & $0 / 12(0)$ & $12 / 12(100)$ & $19 / 19(100)$ \\
\hline & Total & $1 / 24(4.2)$ & 0/24 (0) & 23/24 (95.8) & $42 / 45$ (93.3) \\
\hline \multirow{3}{*}{ MALT Iymphoma } & Low grade & $3 / 26(11.5)$ & $9 / 26(34.6)$ & $14 / 26(53.9)$ & $7 / 10(70)$ \\
\hline & High grade $^{d}$ & $0 / 10(0)$ & $2 / 10(20)$ & $8 / 10(80)$ & $7 / 7(100)$ \\
\hline & Total & $3 / 36(8.3)$ & $11 / 36(30.6)$ & $22 / 36(61.1)$ & $14 / 17(82.4)$ \\
\hline MCL & & $1 / 13(7.7)$ & 0/13 (0) & $12 / 13$ (92.3) & $3 / 4(75)$ \\
\hline Plasmacytoma & & 0/17 (0) & 0/17 (0) & 17/17 (100) & $5 / 5(100)$ \\
\hline \multirow{4}{*}{ FL } & Grade 1 & $0 / 6(0)$ & $0 / 6(0)$ & $6 / 6(100)$ & $11 / 11(100)$ \\
\hline & Grade 2 & $0 / 6(0)$ & $0 / 6(0)$ & 6/6 (100) & $9 / 10(90)$ \\
\hline & Grade 3 & $0 / 2(0)$ & $0 / 2(0)$ & $2 / 2(100)$ & $3 / 3(100)$ \\
\hline & Total & $0 / 14(0)$ & $0 / 14(0)$ & $14 / 14(100)$ & $23 / 24(95.8)$ \\
\hline PBMCs & Healthy donor & $11 / 11(100)$ & $0 / 11(0)$ & $0 / 11(0)$ & $0 / 11(0)$ \\
\hline \multirow{3}{*}{ RLH } & Germinal center & $0 / 10(0)$ & $0 / 10(0)$ & $10 / 10(100)$ & n.d. \\
\hline & Mantle zone & 10/10 (100) & $0 / 10(0)$ & 0/10 (0) & n.d. \\
\hline & Interfollicular & $6 / 10(60)$ & $4 / 10(40)$ & 0/10 (0) & n.d. \\
\hline
\end{tabular}

DLBCL, diffuse large B-cell lymphoma; MALT Iymphoma, marginal zone lymphoma MALT type; MCL, mantle cell lymphoma;

FL, follicular lymphoma; PBMCs, peripheral blood mononuclear cells; RLH, reactive lymphoid hyperplasia; n.d., not done.

${ }^{a}$ Detected by immunohistochemical staining with tissue microarray and standard immunohistochemistry.

${ }^{b}$ Detected by methylation-specific PCR.

${ }^{c}$ The number of expression-positive or methylation-positive samples/the number of total samples.

${ }^{d}$ DLBCL with MALT Iymphoma.

Interestingly, the frequency of the SHP1 gene CpG island methylation was significantly higher in highgrade MALT lymphoma than in low-grade MALT lymphoma. This result correlated with expression of the SHP1 protein, such that no SHP1 protein was detected in $80 \%(8 / 10)$ of high-grade MALT lymphoma cases, whereas 54\% (14/26) of low-grade MALT lymphoma cases did not show SHP1 protein (Table 2). This suggests that reduced expression of SHP1 protein, along with the SHP1 gene CpG island methylation, is related to B-cell lymphoma/leukemia progression in addition to malignant transformation.

SHP1 is known to be an important negative regulator of antigen receptor signaling and selection in B-lymphocytes (Cyster and Goodnow, 1995; Pani et al, 1995). Previous reports have shown that loss of heterozygosity $(\mathrm{LOH})$ on chromosome 12 , where the SHP1 gene is located, occurred at a high frequency in blast cells from patients with leukemia (Oka et al, 2002). LOH analysis of the B-cell lymphoma specimens was not performed in the present study as we were unable to acquire the corresponding normal tissues. However, our study did determine that one of the causes that suppressed the expression of the SHP1 gene in B-cell lineage cells was the methylation of the CpG island in the SHP1 promoter. Moreover, transfection of the SHP1 expression vector to the leukemia cells, which do not express the SHP1 gene, induced the significant growth inhibition. It indicates that gene silencing of the SHP1 gene by aberrant methylation is playing an important role to get the growth advantage of the malignant lymphomas/leukemias cells. This data was supported by the previous report (Bruecher-Encke et al, 2001). It strongly sug- gests that the SHP1 gene acts as a tumor suppressor gene in lymphomas and leukemias.

In the physiological condition, germinal center B lymphocytes show down-regulated expression of the SHP1 gene (Delibrias et al, 1997; Oka et al, 2001). This suppression of the SHP1 gene expression is characteristic for the centroblast/centrocyte, possibly reflecting a requirement at this stage of $B$ cell development for a low threshold for signaling via certain receptors and membrane immunoglobulin, facilitating the signal transduction required for the clonal expansion in germinal center, isotype switching, hypermutation, and selection of high affinity memory B cells. Interestingly, expression of SHP1 protein was transiently inhibited and recovered gradually after stimulation of PMA (phorbol ester) in healthy PBMCs, indicating that the SHP1 gene expression is down-regulated by the stimulating signals as in the germinal center in the physiological condition (Oka et al, 2001). From this aspect, healthy PBMCs, strongly expressing SHP1 protein with unmethylated $\mathrm{CpG}$ island of the SHP1 gene, are reasonable for the positive control (Fig. 1C). Downregulated expression of the SHP1 gene in Burkitt lymphoma was discussed as the germinal center phenotype of Burkitt lymphoma (Delibrias et al, 1997). However, reduced expression of the SHP1 gene is highly frequent in almost all lymphomas/leukemias, not only in Burkitt lymphoma (Oka et al, 2001), indicating gene silencing of the SHP1 gene is one of the critical events of lymphomagenesis/leukemogenesis in the wide range of hematopoietic malignancies. Present investigation clearly shows that aberrant methylation of the SHP1 gene CpG island is an 
A
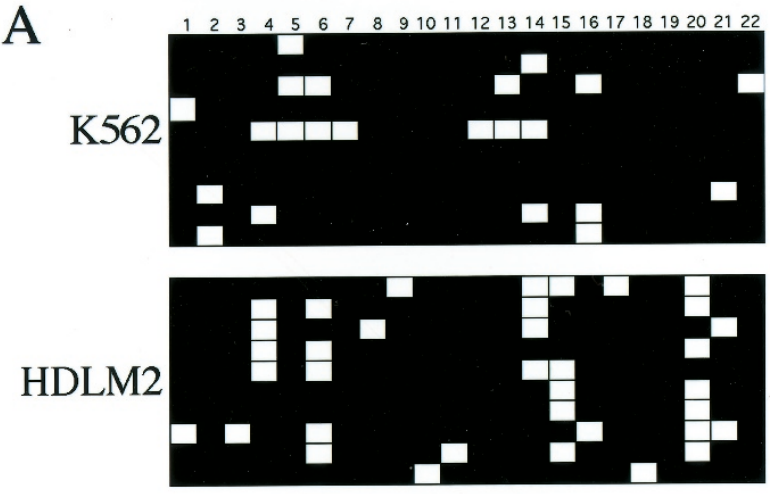

L1844

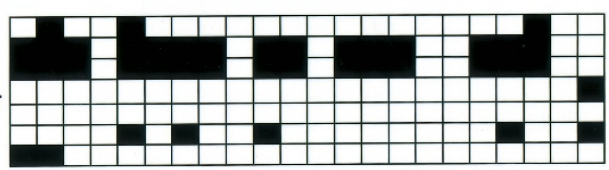

B

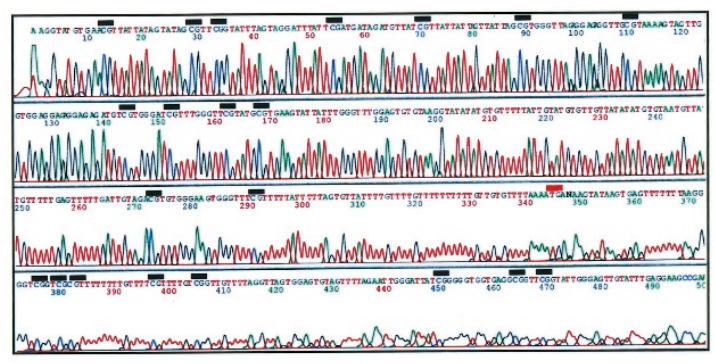

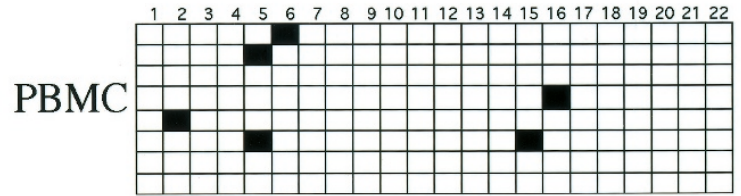

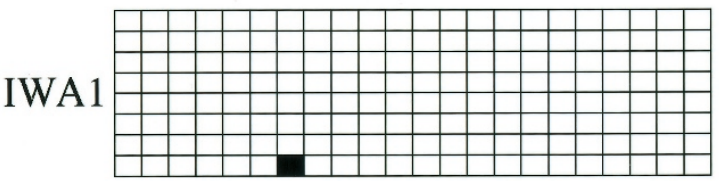

L1675

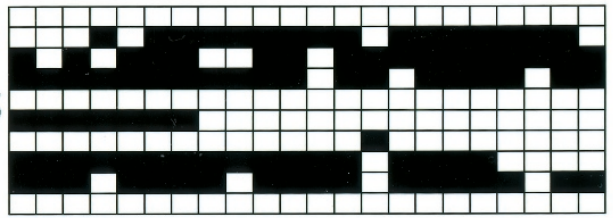

L1568

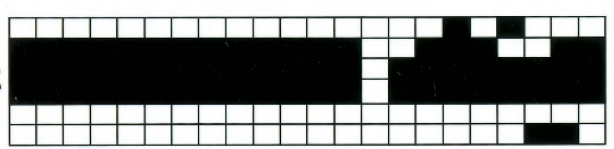

Figure 3.

DNA methylation of the SHP1 gene in cell lines and patient samples detected by DNA sequencing. (A) PCR products of 6 to 10 clones were sequenced from bisulfite treated DNA. Each row of squares represents a single cloned allele, and column represents each of the 22 possible methylated sites in the exon $1 \mathrm{~b}$ promoter region of the SHP1 gene (nucleotide numbers 7002-7520 of GenBank accession number AB079851). Filled and open squares represent methylated and unmethylated cytosines, respectively. (B) DNA sequence in K562. Black and red squares represent methylated and unmethylated sites, respectively.

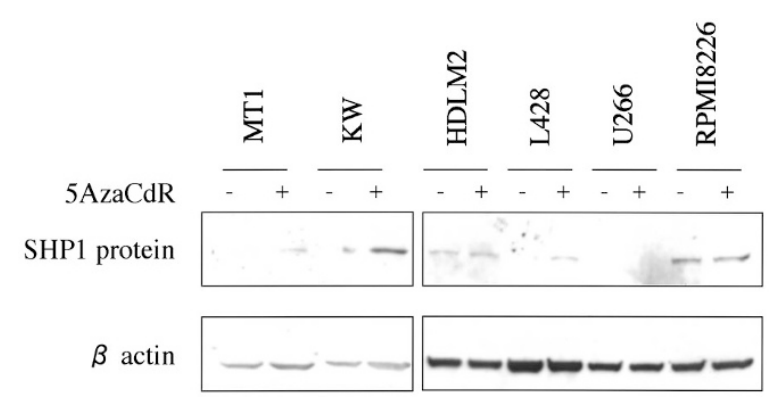

Figure 4.

Rescue of reduced SHP1 protein expression by 5AzaCdR treatment. Western blot analysis of SHP1 protein in cell lines with or without demethylating reagent 5 AzaCdR. Cell lines used were an ATL patient-derived (MT1), B-ALL (KW), Hodgkin's disease (HDLM2 and L428), and multiple myeloma (U266 and MOLP2) cell lines. - , without treatment; +, with treatment.

important mechanism for its gene silencing in B cell lymphomas/leukemias.

The epigenetic silencing of tumor-suppressor genes is interesting from a clinical standpoint for a number of reasons. First, DNA methylation is the only epigenetic feature preserved in genomic DNA isolated from tumors or biopsy specimens. Thus, DNA methylation analysis would be of great clinical value if the diag- nostic and prognostic relevance of particular DNA methylation patterns could be established. Therefore, SHP1 may prove useful as a diagnostic or prognostic marker. Second, it is possible to reverse epigenetic changes and restore gene function to a cell. Treatment with DNA methylation inhibitors can restore the activities of dormant genes and decrease the growth rate of cancer cells in a heritable fashion (Bender et al, 1998). It would become another option in addition to the gene therapy with the introduction of an intact gene. Inhibition of DNA methylation can suppress tumor initiation and reduce the rate of disease progression. In fact, $5 \mathrm{AzaCdR}$, also known as Decitabine, induces cell differentiation and has been used in clinical trials for the treatment of several hematopoietic disorders (Cyster and Goodnow, 1995; Pinto and Zagonel, 1993; Willemze et al, 1997). However, the incorporation of nucleotide analogues into patient DNA has been shown to be mutagenic (JacksonGrusby et al, 1997), and the relationship between clinical efficacy and target gene demethylation has not yet been demonstrated. Nonetheless, epigenetic analysis of global DNA methylation patterns may help to identify those patients who would particularly benefit from DNA methylation inhibiting treatments. 
A

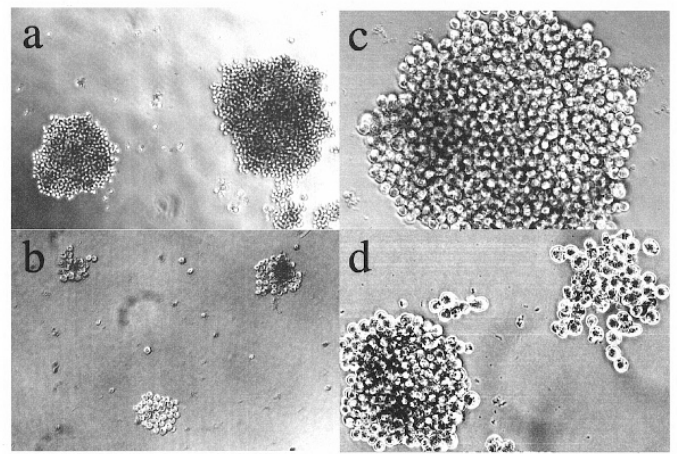

B

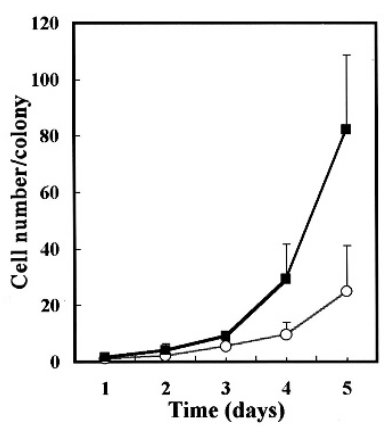

Figure 5.

Growth suppression of K562 cells by exogenous SHP1. (A) K562 cells transfected with SHP1 expression vector (b and d) or empty vector (a and c) were selected with G418 for 7 days and observed with magnification of $\times 40$ ( $a$ and $b$ ) or $\times 100$ ( $c$ and $d)$. (B) Cell number per colony was counted for the K562 cells transfected with SHP1 expression vector (O) or empty vector (घ).

\section{Materials and Methods}

\section{Cell Lines and Tissues}

Human NK cell line NK-YS (Tsuchiyama et al, 1998) was maintained in Iscove's modified Dulbecco's medium (IMDM; GIBCO, Grand Island, New York) supplemented with $10 \%$ FCS (FCS), $100 \mathrm{U} / \mathrm{ml}$ recombinant human IL-2, $100 \mathrm{U} / \mathrm{ml}$ kanamycin, and $100 \mu \mathrm{g} / \mathrm{ml}$ streptomycin. All other cell lines were maintained in RPMI-1640 supplemented with $10 \%$ FCS, $100 \mathrm{U} / \mathrm{ml}$ kanamycin, and $100 \mu \mathrm{g} / \mathrm{ml}$ streptomycin. The human B-acute lymphoblastic leukemia (ALL) cell line KCA was obtained from Dr. E.C. Butcher (Department of Pathology, Stanford University, Stanford, California). Human chronic myelogenous leukemia (CML) (K562), B-ALL (BALL1), Burkitt lymphoma (Ramos and Daudi), Hodgkin's disease (HDLM2 and L428), and multiple myeloma (U266, MOLP2, and RPMI8226) cell lines were obtained from Dr. Y. Matsuo (Fujisaki Cell Center, Hayashibara, Biomedical Laboratories, Okayama, Japan). B-ALL (SCOTT and KW), mantle cell lymphoma (SP53, SP50B, and SP49) (Daibata et al, 1989), human T cell line immortalized by HTLV-I (IWA1), and adult $\mathrm{T}$ cell leukemia/lymphoma (MT1) (Miyoshi et al, 1980) cell lines were also used. Peripheral blood mononuclear cells (PBMCs) from healthy volunteers were isolated by the Ficoll-Hypaque density centrifugation method performed according to the manufac- turer's protocols. Tissue sections were made from lymph nodes from patients with malignant lymphoma after obtaining an informed consent from each patient.

\section{Tissue Microarray Analysis}

Paraffin-embedded tissue samples, consisting of primary malignant lymphomas of different histological categories and normal reactive lymphoid hyperplasia $(\mathrm{RLH})$, were used for malignant lymphoma tissue microarrays. Core tissue biopsies ( $0.8 \mathrm{~mm}$ diameter) were taken from selected regions of individual paraffin-embedded malignant lymphoma specimens (donor block) and precisely arrayed onto a new recipient paraffin block ( $50 \mathrm{~mm} \times 23 \mathrm{~mm}$ ) using a custombuilt instrument. After block construction was completed, $5-\mu \mathrm{m}$ sections of the resulting malignant lymphoma tissue microarray block were cut with a microtome, and specimens were used for hematoxylin-eosin staining and immunostaining according to standard procedures with rabbit polyclonal antibody against the C-terminal region of SHP1 (SHPTP1C-19 SC287; Santa Cruz Biotechnology Inc., Santa Cruz, California).

\section{Western Blot Analysis}

Western blot analysis was performed as previously described (Oka et al, 2001). Briefly, following 12\% polyacrylamide gel electrophoresis of cellular protein lysates from $7.5 \times 10^{4}$ cells from each culture, separated proteins were electrophoretically transferred onto polyvinylidene difluoride membranes (Immobilon; Millipore Ltd., Bedford, Massachusetts). Membranes were then reacted with rabbit polyclonal antibody against the C-terminal region of SHP1 (SHPTP1C-19 SC287; Santa Cruz Biotechnology Inc.) and monoclonal anti- $\beta$-actin (Sigma, St. Louis, Missouri). Immunoreactive bands were visualized using peroxidaselabeled goat anti-rabbit or anti-mouse lg (Ig) (Amersham-Pharmacia Company, Ltd., Piscataway, New Jersey) and the enhanced chemiluminescence (ECL)-SuperSignal Western blotting system (Pierce, Rockford, Illinois), and exposed to x-ray film.

\section{Analysis of mRNA Expression by Reverse Transcription-Polymerase Chain Reaction (RT-PCR)}

Aliquots $(2 \mu \mathrm{g})$ of DNase I-treated total cellular RNA were reverse-transcribed with SuperScriptll reverse transcriptase (Invitrogen Life Technologies, Carlsbad, California) at $42^{\circ} \mathrm{C}$ for 50 minutes. Reactions were terminated by incubation at $70^{\circ} \mathrm{C}$ for 15 minutes and treated with $\mathrm{RNase} \mathrm{H}$ at $37^{\circ} \mathrm{C}$ for 20 minutes. Aliquots $(0.5 \mu \mathrm{l})$ of single-stranded cDNA were amplified by PCR using SHP1-specific primers (sequences obtained from BD Biosciences Clontech). PCR was performed using Platinum PCR Super Mix (Invitrogen Life Technologies). Amplification conditions consisted of 2 minutes pretreatment at $94^{\circ} \mathrm{C}$, followed by 30 cycles of denaturation $\left(94^{\circ} \mathrm{C}\right.$ for 30 seconds), annealing $\left(55^{\circ} \mathrm{C}\right.$ for 30 seconds), and extension $\left(72^{\circ} \mathrm{C}\right.$ for 1 
minute 30 seconds), followed by a final extension (72 ${ }^{\circ} \mathrm{C}$ for 10 minutes).

\section{Methylation-Specific PCR (MSP) and Unmethylation-Specific PCR (unMSP) Assay}

Sodium bisulfite modification of DNA was performed using the CpGenome DNA modification kit (Intergen Company, Purchase, New York). Briefly, 2- $\mu$ g aliquots of genomic DNA were denatured by $\mathrm{NaOH}$ and modified by sodium bisulfite, which converts all unmethylated cytosines to uracils while leaving methylated cytosines unaltered. Modified DNA was purified, treated with $\mathrm{NaOH}$ to desulfonate, precipitated with ethanol, and resuspended in TE buffer. The methylation-specific primer sequences used were $5^{\prime}$ TGT GAA CGT TAT TAT AGT ATA GCG-3' (sense) and 5'-CCA AAT AAT ACT TCA CGC ATA CG-3' (antisense). These primers were designed from the methylated sequence of the promoter region for exon $1 \mathrm{~b}$ of the SHP1 gene (nucleotide numbers 7034-7207 of GenBank accession number AB079851). Initial denaturation at $94^{\circ} \mathrm{C}$ for 3 minutes was followed by 40 cycles of denaturation ( $94^{\circ} \mathrm{C}$ for 30 seconds), annealing $\left(58^{\circ} \mathrm{C}\right.$ for 1 minute), and extension $\left(72^{\circ} \mathrm{C}\right.$ for 1 minute), and a final extension step of $72^{\circ} \mathrm{C}$ for 7 minutes. The unmethylation-specific primer sequences were 5'-GTG AAT GTT ATT ATA GTA TAG TGT TTG G-3' (sense) and 5'-TTC ACA CAT ACA AAC CCA AAC AAT-3' (antisense) (nucleotide numbers 7035-7196 in GenBank accession number AB079851. Initial denaturation at $94^{\circ} \mathrm{C}$ for 3 minutes was followed by 40 cycles of denaturation $\left(94^{\circ} \mathrm{C}\right.$ for 30 seconds), annealing $\left(61^{\circ} \mathrm{C}\right.$ for 1 minute), and extension $\left(72^{\circ} \mathrm{C}\right.$ for 1 minute), and a final extension step of $72^{\circ} \mathrm{C}$ for 7 minutes. PCR products were separated by electrophoresis on $10 \%$ polyacrylamide gels.

\section{Methylation Analysis of Promoter Region with Restriction Enzymes-Mediated PCR (RE-PCR)}

Genomic DNA extraction of $1 \times 10^{7}$ cell aliquots was performed using a DNA extraction kit (Stratagene, La Jolla, California). A primer pair (sense 5'-CAA AGC ACT GGC TIT GGA ACC and antisense 5'-ATC GAG TGA GTC CTG CTG GAT) was designed to enclose Hpall/Mspl restriction sites in the promoter region of the SHP1 gene (nucleotide number 6858-7094 in GenBank accession number AB079851). DNA (50 ng) was digested with 20 units of Hpall or Mspl (New England Biolabs, Beverly, Massachusetts) in $1 \times$ buffer at $37^{\circ} \mathrm{C}$ for 24 hours. Enzyme digestions were halted by heating at $65^{\circ} \mathrm{C}$ for 20 minutes and PCR was performed in $20 \mu \mathrm{l}$ reaction mixtures containing 20 pmole each primer, $2.5 \mathrm{ng}$ genomic DNA, $1 \times \mathrm{PCR}$ buffer, $200 \mu \mathrm{M}$ each dNTP, $2 \mathrm{~mm} \mathrm{MgCl}_{2}$, and 0.5 unit TaqDNA polymerase (Invitrogen Life Technologies). Initial denaturation at $94^{\circ} \mathrm{C}$ for 5 minutes was followed by 33 cycles of denaturation $\left(94^{\circ} \mathrm{C}\right.$ for 30 seconds), annealing $\left(62^{\circ} \mathrm{C}\right.$ for 1 minute) and extension $\left(72^{\circ} \mathrm{C}\right.$ for 1 minute), and a final extension step of $72^{\circ} \mathrm{C}$ for 10 minutes. Resulting products were separated by electrophoresis on $1.5 \%$ agarose gels.

\section{Bisulfite DNA Sequencing}

Primers were designed to amplify a $519 \mathrm{bp}$ region of the SHP1 promoter containing the noncoding region of exon 1b. The primer sequences used were 5'-GGG TTG TGG TGA GAA ATT AAT TAG-3' (sense) and 5'-CCT CAA ATA CAA CTC CCA ATA CC-3' (antisense) (nucleotide numbers 7002-7520 of GenBank accession number AB079851). Initial denaturation at $94^{\circ} \mathrm{C}$ for 3 minutes was followed by 40 cycles of denaturation $\left(94^{\circ} \mathrm{C}\right.$ for 30 seconds), annealing $\left(64^{\circ} \mathrm{C}\right.$ for 1 minute) and extension ( $72^{\circ} \mathrm{C}$ for 1 minute), and a final extension step of $72^{\circ} \mathrm{C}$ for 7 minutes. PCR amplification products were separated on $1.5 \%$ agarose gels, visualized, and purified by using the Geneclean II kit (BIO101, Inc., Carlsbad, California). Purified products were phosphorylated by T4 DNA kinase and cloned into the pBluescript KS vector. Independent plasmid clones were purified from several bacterial colonies and subjected to sequencing using the BigDye Terminator Cycle Sequencing Ready Reaction Kit V2.0 (Applied Biosystems, Foster City, California) and an ABI Prism 3100 DNA sequencer (Applied Biosystems).

\section{Southern Blot Analysis}

According to standard methods, $1-\mu \mathrm{g}$ genomic DNA aliquots were digested with $E c o R l$, and the digested DNA was purified by phenol/chloroform extraction, ethanol precipitated, separated on $0.8 \%$ agarose gel electrophoresis, and transferred to Hybond $\mathrm{N}+$ nylon membranes. Membranes were hybridized with full length SHP1 cDNA probe labeled with fluorescein-11dUTP. Membranes were washed in buffer containing $0.2 \times$ standard saline citrate and $0.1 \%$ sodium dodecyl sulfate at $60^{\circ} \mathrm{C}$, and DNA was detected using a chemiluminescence detection kit (Gene Images random prime labeling and detection system, Amersham Life Science, Buckinghamshire, United Kingdom) according to the manufacturer's protocol.

\section{AzaCdR Treatment}

For examination of SHP1 promoter demethylation, hematopoietic cell lines were incubated with or without $1 \mu \mathrm{M} 5 \mathrm{AzaCdR}$ (5-aza-2'-deoxycytidine; Sigma) for 5 days. Cells were harvested and tested for SHP1 protein expression by ECL Western blotting.

\section{Cell Growth Assay}

K562 cells were transfected with pCMV-SHP1 by X-tremeGENE Q2 transfection reagent (Roche Diagnostics Corporation, Indianapolis, Indiana). At 48 hours after transfection, the cells were distributed in 24-well plate with the culture medium containing 200 $\mu \mathrm{g} / \mathrm{ml} \mathrm{G418.} \mathrm{Colony} \mathrm{formation} \mathrm{of} \mathrm{the} \mathrm{transformed}$ cells was observed under the microscopy after leaving for 7 days. 


\section{Acknowledgements}

The authors gratefully acknowledge Dr. Yoshinobu Matsuo (Fujisaki Cell Center, Hayashibara, Biomedical Laboratories, Okayama, Japan) for his kind provision of the cell lines K562, BALL1, Ramos, Daudi, HDLM2, L428, U266, MOLP2, and RPMI8226; Dr. E.C. Butcher (Department of Pathology, Stanford University, Stanford, California) for provision of the KCA cell line; Dr. Jungirou Tsuchiyama (Department of Medicine, Niigata University, Niigata, Japan) for provision of the NK-YS cell line; and Dr. Shi-Hsiang Shen (Biotechnology Research Institute, National Research Council, Canada) for the generous supply the PCMV-SHP1. The authors also acknowledge Mutumi Okabe, Yoshiko Sakamoto, Hiromi Nakamura, Yuki Onoda, and Miyuki Shiotani from the Department of Pathology, Okayama University Medical School, and Hiroshi Okamoto and Ai Tomosada from the Central Research Laboratory, Okayama University Medical School, for their excellent technical assistance. The authors also gratefully acknowledge Okayama University Hospital, National Okayama Medical Center, Fukuyama National Hospital, Okayama Saiseikai General Hospital, Toyama Prefectural Central Hospital, Chugoku Central Hospital, and Okayama Red Cross General Hospital for generously supplying the patient specimens.

\section{References}

Bender CM, Pao MM, and Jones PA (1998). Inhibition of DNA methylation by 5-aza-2'-deoxycytidine suppresses the growth of human tumor cell lines. Cancer Res 58:95-101.

Brown R and Strathdee G (2002). Epigenomics and epigenetic therapy of cancer. Trends Mol Med 8:S43-S48.

Bruecher-Encke B, Griffin JD, Neel BG, and Lorenz U. ( 2001) Role of the tyrosine phosphatase SHP-1 in K562 cell differentiation. Leukemia. 15(9):1424-1432.

Carter JD, Neel BG, and Lorenz U (1999). The tyrosine phosphatase SHP-1 influences thymocyte selection by setting TCR signaling thresholds. Int Immunol 11:1999-2014.

Chung D (2002). Histone modification: The 'next wave' in cancer therapeutics. Trends Mol Med 8:S10-S11.

Cyster JG and Goodnow CC (1995). Protein tyrosine phosphatase $1 \mathrm{C}$ negatively regulates antigen receptor signaling in $B$ lymphocytes and determines thresholds for negative selection. Immunity 2:13-24.

Daibata M, Kubonishi I, Eguchi T, Yano S, Ohtsuki Y, and Miyoshi I (1989). The establishment of Epstein-Barr virus nuclear antigen-positive (SP-50B) and Epstein-Barr virus nuclear antigen-negative (SP-53) cell lines with $\mathrm{t}(11 ; 14)(\mathrm{q} 13$; q32) chromosome abnormality from an intermediate lymphocytic lymphoma. Cancer 64:1248-1253.

Delibrias CC, Floettmann JE, Rowe M, and Fearon DT (1997). Downregurated expression of SHP-1 in Burkitt lymphomas and germinal center B lymphocytes. J Exp Med 186:15751583.

Esteller M, Corn PG, Baylin SB, and Herman JG (2001). A gene hypermethylation profile of human cancer. Cancer Res 61:3225-3229.
Esteller M, Hamilton SR, Burger PC, Baylin SB, and Herman JG (1999a). Inactivation of the DNA repair gene O6methylguanine-DNA methyltransferase by promoter hypermethylation is a common event in primary human neoplasia. Cancer Res 59:793-797.

Esteller M and Herman JG (2002). Cancer as an epigenetic disease: DNA methylation and chromatin alterations in human tumors. J Pathol 196:1-7.

Esteller M, Sanchez-Cespedes M, Rosell R, Sidransky D, Baylin SB, and Herman JG (1999b). Detection of aberrant promoter hypermethylation of tumor suppressor genes in serum DNA from non-small cell lung cancer patients. Cancer Res 59:67-70.

Esteller M, Silva JM, Dominguez G, Bonilla F, Matias-Guiu X, Lerma E, Bussaglia E, Prat J, Harkes IC, Repasky EA, Gabrielson E, Schutte M, Baylin SB, and Herman JG (2000). Promoter hypermethylation and BRCA1 inactivation in sporadic breast and ovarian tumors. J Natl Cancer Inst 92:564569.

Fleisher AS, Esteller M, Wang S, Tamura G, Suzuki H, Yin J, Zou TT, Abraham JM, Kong D, Smolinski KN, Shi YQ, Rhyu MG, Powell SM, James SP, Wilson KT, Herman JG, and Meltzer SJ (1999). Hypermethylation of the hMLH1 gene promoter in human gastric cancers with microsatellite instability. Cancer Res 59:1090-1095.

Fulda S, Kufer MU, Meyer E, van Valen F, DockhornDworniczak B, and Debatin KM (2001). Sensitization for death receptor- or drug-induced apoptosis by re-expression of caspase-8 through demethylation or gene transfer. Oncogene 20:5865-5877.

Greger V, Passarge E, Hopping W, Messmer E, and Horsthemke B (1989). Epigenetic changes may contribute to the formation and spontaneous regression of retinoblastoma. Hum Genet 83:155-158.

Herman JG, Jen J, Merlo A, and Baylin SB (1996). Hypermethylation-associated inactivation indicates a tumor suppressor role for p15INK4B. Cancer Res 56:722-727.

Herman JG, Merlo A, Mao L, Lapidus RG, Issa JP, Davidson NE, Sidransky D, and Baylin SB (1995). Inactivation of the CDKN2/p16/MTS1 gene is frequently associated with aberrant DNA methylation in all common human cancers. Cancer Res 55:4525-4530.

Herman JG, Umar A, Polyak K, Graff JR, Ahuja N, Issa JP, Markowitz S, Wilson JK, Hamilton SR, Kinzler KW, Kane MF, Kolodner RD, Vogelstein B, Kunkel TA, and Baylin SB (1998). Incidence and functional consequences of hMLH1 promoter hypermethylation in colorectal carcinoma. Proc Natl Acad Sci USA 95:6870-6875.

Jackson-Grusby L, Laird PW, Magge SN, Moeller BJ, and Jaenisch R (1997). Mutagenicity of 5-aza-2'-deoxycytidine is mediated by the mammalian DNA methyltransferase. Proc Natl Acad Sci USA 94:4681-4685.

Jenuwein T and Allis CD (2001). Translating the histone code. Science 293:1074-1080.

Katzenellenbogen RA, Baylin SB, and Herman JG (1999). Hypermethylation of the DAP-kinase CpG island is a common alteration in B-cell malignancies. Blood 93:4347-4353.

Lorenz U, Bergemann AD, Steinberg HN, Flanagan JG, Li X, Galli SJ, Neel BG (1996). Genetic analysis reveals cell type- 
specific regulation of receptor tyrosine kinase c-Kit by the protein tyrosine phosphatase SHP1. J Exp Med 184:11111126.

Merlo A, Herman JG, Mao L, Lee DJ, Gabrielson E, Burger PC, Baylin SB, and Sidransky D (1995). 5' CpG island methylation is associated with transcriptional silencing of the tumor suppressor $\mathrm{p} 16 / \mathrm{CDKN} 2 / \mathrm{MTS} 1$ in human cancers. Nat Med 1:686-692.

Miyoshi I, Kubonishi I, Sumida M, Hiraki S, Tsubota T, Kimura I, Miyamoto K, and Sato J (1980). A novel T-cell line derived from adult T-cell leukemia. Gann 71:155-156.

Ohtani-Fujita N, Dryja TP, Rapaport JM, Fujita T, Matsumura S, Ozasa K, Watanabe Y, Hayashi K, Maeda K, Kinoshita S, Matsumura T, Ohnishi Y, Hotta Y, Takahashi R, Kato MV, Ishizaki K, Sasaki MS, Horsthemke B, Minoda K, and Sakai T (1997). Hypermethylation in the retinoblastoma gene is associated with unilateral, sporadic retinoblastoma. Cancer Genet Cytogenet 98:43-49.

Oka T, Ouchida M, Koyama M, Ogama Y, Takada S, Nakatani Y, Tanaka T, Yoshino T, Hayashi K, Ohara N, Kondo E, Takahashi K, Tsuchiyama J, Tanimoto M, Shimizu K, and Akagi T (2002). Gene silencing of the tyrosine phosphatase SHP1 gene by aberrant methylation in leukemias/lymphomas. Cancer Res 62:6390-6394.

Oka T, Yoshino T, Hayashi K, Ohara N, Nakanishi T, Yamaai Y, Hiraki A, Sogawa CA, Kondo E, Teramoto N, Takahashi K, Tsuchiyama J, and Akagi T (2001). Reduction of hematopoietic cell-specific tyrosine phosphatase SHP-1 gene expression in natural killer cell lymphoma and various types of lymphomas/leukemias: Combination analysis with cDNA expression array and tissue microarray. Am J Pathol 159:14951505.

Pani G, Fischer KD, Mlinaric-Rascan I, and Siminovitch KA (1996). Signaling capacity of the T cell antigen receptor is negatively regulated by the PTP1C tyrosine phosphatase. J Exp Med 184:839-852.
Pani G, Kozlowski M, Cambier JC, Mills GB, and Siminovitch KA (1995). Identification of the tyrosine phosphatase PTP1C as a $B$ cell antigen receptor-associated protein involved in the regulation of B cell signaling. J Exp Med 181:2077-2084.

Pinto A and Zagonel V (1993). 5-Aza-2'-deoxycytidine (Decitabine) and 5-azacytidine in the treatment of acute myeloid leukemias and myelodysplastic syndromes: Past, present and future trends. Leukemia 7:51-60.

Prowse AH, Webster AR, Richards FM, Richard S, Olschwang S, Resche F, Affara NA, and Maher ER (1997). Somatic inactivation of the VHL gene in Von Hippel-Lindau disease tumors. Am J Hum Genet 60:765-771.

Razin A and Cedar H (1991). DNA methylation and gene expression. Microbiol Rev 55:451-458.

Robertson KD and Jones PA (1998). The human ARF cell cycle regulatory gene promoter is a $\mathrm{CpG}$ island which can be silenced by DNA methylation and down-regulated by wildtype p53. Mol Cell Biol 18:6457-6473.

Sakai T, Toguchida J, Ohtani N, Yandell DW, Rapaport JM, and Dryja TP (1991). Allele-specific hypermethylation of the retinoblastoma tumor-suppressor gene. Am J Hum Genet 48:880-888.

Tsuchiyama J, Yoshino T, Mori M, Kondoh E, Oka T, Akagi T, Hiraki A, Nakayama H, Shibuya A, Ma Y, Kawabata T, Okada $S$, and Harada M (1998). Characterization of a novel human natural killer-cell line (NK-YS) established from natural killer cell lymphoma/leukemia associated with Epstein-Barr virus infection. Blood 92:1374-1383.

Willemze R, Suciu S, Archimbaud E, Muus P, Stryckmans $\mathrm{P}$, Louwagie EA, Berneman Z, Tjean M, Wijermans P, Dohner H, Jehn U, Labar B, Jaksic B, Dardenne M, and Zittoun R (1997). A randomized phase II study on the effects of 5-Aza-2'deoxycytidine combined with either amsacrine or idarubicin in patients with relapsed acute leukemia: An EORTC Leukemia Cooperative Group phase II study (06893). Leukemia 11:S24-S27. 